\title{
EXTROVERT PERSONALITY AND ITS IMPACT ON STUDENTS' ARGUMENTATIVE ESSAY WRITING SKILL
}

\author{
Wida Sopia Marwa \\ Department of English Education, University of Kuningan, Indonesia \\ E-mail: widasw@gmail.com \\ Nani Ronsani Thamrin \\ Department of English Education, University of Kuningan, Indonesia \\ E-mail: nani_cute@yahoo.com
}

APA Citation: Marwa, W. S., \& Thamrin, N. R. (2016). Extrovert personality and its impact on students' argumentative essay writing skill. English Review, 4(2), 267-274

\begin{abstract}
This research aims at finding the positive correlation between extroversion personality and students' argumentative essay writing skill. The objective of this research is to know the correlation between extroversion personality and students' argumentative essay of sophomore English Department students in University of Kuningan. The population in this research was all sophomore English Department students with total 60 students. A convenience purposive sampling was applied to get the sample students. The samples of this research were 12 extrovert students. From the results of statistical tests to test the correlation between two variables, this research used Pearson product moment. As the result of the calculation, it was found that $r_{\text {observed }}(0,778)>t_{\text {tables }}(0,532)$. Then, based on the hypothesis test with two tail test, the result of hypothesis test obtained $t_{\text {observed }}(3,917)>$ $t_{\text {tables }}(1,782)$. Thus, it can be concluded that Ha was accepted and there was a correlation between extroversion personality and students' argumentative essay writing skill.

Keywords: extroversion personality, argumentative essay, writing, Eysenk personality inventory
\end{abstract}

\section{INTRODUCTION}

The result of skill language achievement can be influenced by personality, as Boroujeni, Roohani, \& Hasanimanesh, (2015) argued that "the way we learn is very much affected by our personality." According to Larsen \& Buss (2005), in Boroujeny et al. (2015), personality is "the set of psychological traits and mechanism within the individual that are organized and relatively enduring that influence his or her interaction with, and adaptations to, the intrapsychic, physical, and social environment." Every student has different personality that will bring them to achieve something in their life. According to Kant (1804) in Sullivan (1989), there are four personality types namely choleric (extroversion), sanguine, phlegmatic, and melancholic (introversion).

One of the basic language skills of English is writing. Writing seems as the most difficult skill to be learnt and produced by students and maybe that is why in the order of four skills of English it is referred to as the last one (Nama \& Moini, 2013). As Kim \& Dung (2004) declare in Nama \& Moini (2013) that "writing or composition has been defined in a variety of ways which shows a lack of agreement as to what composition is, and reflects the complexity of the writing process." Most of the researches in English language learning with respect to 
extraversion/introversion had been concentrated on identifying the qualities of a good language learner and to what extent extraversion influences English language skills particularly oral proficiency (Oya et al., 2004; van Daele, 2005). Unfortunately, there are a few studies that investigated personality variables in writing skills.

Furnham (1990) in his study quoted a study conducted by Thorne (1987) which examined the interaction between introverts and extroverts. The study mixed and matched partners of extroverts and introverts in conversational situations. When introverts were paired with introverts, the conversation they engaged in focused on problem talk (Thorne, 1987). On the other hand, extroverts students show a wide range of topics and more claims of common ground. Furnham (1990) concludes from this study and subsequent observations that extroverts are more impulsive and take more risks with speech than introverts.

Thus, it is worth to investigate whether extroverts are active in writing than introverts where there is less requirement of oral interaction since writing is a way of communication that happens naturally through speaking. However, in writing task, the writer has more time to think about the topic, the materials, things, people, and phenomena which are expected to be involved in a text (Meyers, 2006 in Nezhad et al., 2014).

Extrovert personality is commonly called extroversion or choleric personality. Some of modern experts believe that extrovert personalities are better language learner. Morrone-Strupinsky and Lane (2007: p.1267) as cited in Nama and Moini (2013) declare that extroversion consists of "agentic and affiliative components", which are typified by "distinct positive emotional stated of positive activation and warmth-affection," accordingly. It is well established that extroverts feel higher levels of positive affect than introverts (Costa \& McCrae, 1980; Lucas \& Baird, 2004; Watson \& Clark, 1992) in Wilt \& Revealle (2000).

Usually, the extroverts are more popular and appear in education field. They are active and like to be involved in several positive activities. They are good performers. They are brief, clear, and definite in speaking (Boroujeni et al., 2015). Lightbown and Spada (2006) find that many classroom teachers believe that in second or foreign language learning, extroverts are more successful than introverts, particularly in their communicative ability. Skehan in Shahila (2012) considers three crucial factors of language learning, those are: 1 ) Intelligence, 2) Risk-taking ability, and 3) Extroversion/introversion.

Extroverts work better under stressful situations than introverts. Canli (2004) in Wilt \& Reveale (2000) finds that personality factors like extroversion are likely to be widely distributed in the brain. Many SLA theorists claim that extroverts are the better language learners.

Extroverts, who tend to be sociable, are more likely to join groups, more inclined to engage in conversations both inside (Cook, 1991) and outside the classroom (Swain, 1985) in (Nama \& Moini, 2013).

Uziel (1998) in Wilt \& Revealle (2000) declares that broadly speaking, extroversion relates to a relatively positive view of the world, as extroverts judge neutral events more positively than introverts. Extroversion predicts categorization of words by their positive affective quality rather than their semantic quality (Weiler in Wilt \& Revealle, 2000). In the affect-level model, it is assumed that extroverts have higher tonic level of positive affect (Wilt \& Reveale, 2000). 
Instead of merely categorize people into two big groups of extrovert and introvert people, the researcher decided to make levels of extraversion based on Eysenck-made instrument. As a matter of fact, some people may place in 'between' or balance, others are just fairly and some others place between the most extreme edges. Eysenck used number of each edges showing that there exists stages/levels, ranging from extreme introvert (0) until extreme edge of extrovert (24). Below is part of personality lines based on Eysenck Personality chart (1965).

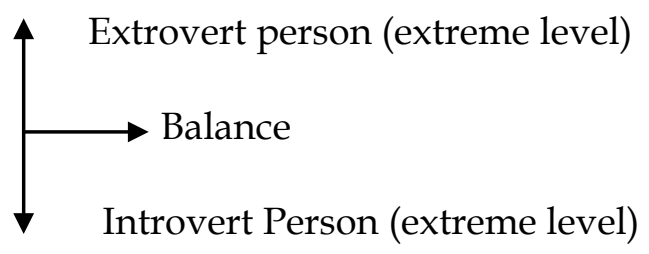

The pieces in this range of writing section represent one of the three types of writing named in the Common Core State Standards for Writing: opinion/ argument writing (The Vermont Collaborative Writing, 2010, p. 118). Argument, on the other hand, is mainly about logical appeals and involves claims, evidence, warrants, backing, and rebuttals, policy making, in courtrooms, and so forth. (Hillocks, 2011, p. 23)

An argumentative essay is an essay in which ones agree or disagree with an issue, and use reasons to support their opinion. The goal is to convince reader that the writer's opinion is right (Oshima \& Hogue, 2005). In line with Oshima and Hogue (2005), Newell et al., (2013, p. 4) defines:

Argumentative writing as a type of critical thinking and rhetorical production involving the identification of a thesis (also called a claim), supportive evidence (empirical or experiential), and assessment of the warrants that connect the thesis, evidence, and situation within which the argument is being made.

\section{METHOD}

There are two variables in this research; the first variable was extroversion personality (variable $X$ ), and the second variable was argumentative essay writing skill (variable Y).The samples in this research were chosen by using purposive sampling technique. This research involved 60 students of sophomore English Department students as the population. Then, 12 extrovert students were chosen to be the samples of the research.

Personality test and writing test were used to collect the data. Eysenk Personality Inventory (EPI) by Eysenk modified by Davies (2004) which functions to determine level of Extraversion of Sample Students was used. While the questions in questionnaire consists of 57 questions. The questions are originally English but are combined with Indonesian. In the questionnaire, there were two columns that provide Yes and No answer.

To test writing skill, the respondents were instructed to write argumentative essays whose topics were specified by the researcher. To obtain the score, the researcher was oriented to Argumentative Essay Rubric by Tony's Language Art (2015). The main aspects considered in the paper or essay and also used as indicator in the assessment of the paper include: content, mechanics of 
writing, paragraphing, spelling, grammar, and punctuation.

Next, to find out the correlation between the two variables, the data were then analyzed by manual statistical perspective. Lilieforce normality test was used to test normality between EPI score and argumentative essay score. To know the final result whether two variables do correlate and show significance to each other, this research used correlation product moment or correlation Pearson by Arikunto (2010). While to find out the significances of hypothesis, the researcher used the significances test of two tail test by Sugiyono (2012, p. 182).

\section{RESULTS AND DISCUSSION}

From the result of spreading the questionnaires to 28 respondents, there were 12 extrovert students, 4 introvert students, and 12 balance or stable students. The types of personality were presented in Figure 1.

Figure 1. The Types of Personality

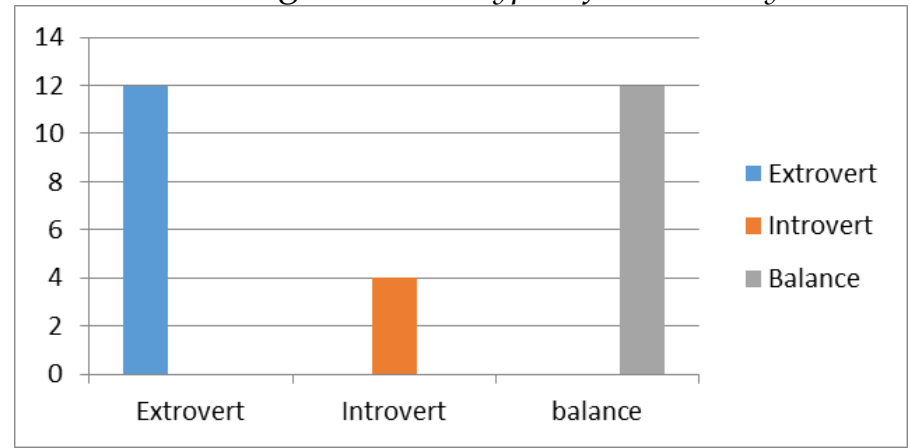

Figure 1 shows that extrovert and stable/balance were equal in which it consists of 12 people, while introvert only 4 people from 28 respondents. Since this research only focuses on extrovert students, so introvert and stable students did not take as samples.
From 12 extrovert students, the researcher then divided them into its level of extroversion based on the total $\mathrm{E}$ score and its successive interval. The following table is the results of EPI questionnaire of extrovert students.

Table 1. The result of EPI questionnaire

\begin{tabular}{lccc}
\hline Respondents & Total E Score & Successive Interval & Type of Personality \\
\hline Student 1 & $19 \mathrm{E}$ & 2,92 & Fairly Extrovert \\
\hline Student 2 & $15 \mathrm{E}$ & 1,00 & Fairly Extrovert \\
\hline Student 3 & $20 \mathrm{E}$ & 3,78 & Extreme Extrovert \\
\hline Student 4 & $17 \mathrm{E}$ & 2,15 & Fairly Extrovert \\
\hline Student 5 & $15 \mathrm{E}$ & 1,00 & Fairly Extrovert \\
\hline Student 6 & $15 \mathrm{E}$ & 1,00 & Fairly Extrovert \\
\hline Student 7 & $18 \mathrm{E}$ & 2,49 & Fairly Extrovert \\
\hline Student 8 & $15 \mathrm{E}$ & 1,00 & Fairly Extrovert \\
\hline Student 9 & $16 \mathrm{E}$ & 1,83 & Fairly Extrovert \\
\hline Student 10 & $17 \mathrm{E}$ & 2,15 & Fairly Extrovert \\
\hline Student 11 & $19 \mathrm{E}$ & 2,92 & Fairly Extrovert \\
\hline Student 12 & $15 \mathrm{E}$ & 1,00 & Fairly Extrovert \\
\hline
\end{tabular}


ENGLISH REVIEW: Journal of English Education Vol. 4, Issue 2, June 2016

Since extrovert students should obtain $15 \mathrm{E}$ to $24 \mathrm{E}$, all the respondents got the E score from range $15 \mathrm{E}$ to $20 \mathrm{E}$, but no one got more than $20 \mathrm{E}$. All the result of $\mathrm{E}$ score were converted into interval data by using successive interval method.

Then, to examine students' writing skill, the researcher used argumentative essay to measure their writing skill. The students were given random topics of argumentative essay where the topics had been specified by the researcher. The students could choose the topics for their essay writing.
ISSN 2301-7554

https://journal.uniku.ac.id/index.php/ERJEE

Table 2. Score of argumentative essay

\begin{tabular}{cccc}
\hline Respondents & Score I & Score II & Final Score \\
\hline Student 1 & 59,33 & 58,33 & 58,83 \\
\hline Student 2 & 35,33 & 31,67 & 33,50 \\
\hline Student 3 & 77,33 & 61,33 & 69,33 \\
\hline Student 4 & 60,67 & 58,00 & 59,33 \\
\hline Student 5 & 63,33 & 42,00 & 52,67 \\
\hline Student 6 & 29,33 & 40,67 & 35,00 \\
\hline Student 7 & 59,00 & 42,00 & 50,50 \\
\hline Student 8 & 50,67 & 41,33 & 46,00 \\
\hline Student 9 & 61,00 & 56,00 & 58,50 \\
\hline Student 10 & 56,33 & 53,17 \\
\hline Student 11 & 50,00 & 77,00 & 72,83 \\
\hline Student 12 & 68,67 & 49,33 & 53,17
\end{tabular}

Data conversion had been done as a requirement to use parametric statistics. Because the collected data was ordinal data, so the data must be converted to interval data. The conversion ordinal data into interval data was done by using successive interval method.

After converting the data, the researcher did Lilieforce Normality test toward EPI score and Argumentative essay. The normality test of EPI (Eysenk Personality Inventory) was done by doing the following stages: 1 ) Determining average (mean) and
The students had to make three argumentative essays with the following topics: (a) Technology is making life easier in today's world; (b) Google makes us stupid, and; (c) Should the death penalty be mandatory to drugs dealers?

The data of argumentative essay score was amounted from 12 students. Then, the total score was obtained from the average score given by two supervisors. To understand the data of argumentative essay score, the data was presented in the table below.

Table 3. Lilieforce Normality Test of Eysenk Personality Inventory Score

\begin{tabular}{cccccccccccc}
\hline $\mathrm{x}$ & $\mathrm{f}$ & $\mathrm{fx}$ & $\mathrm{x}(\mathrm{X}-\mathrm{Me})$ & $\mathrm{x} 2$ & $\mathrm{f} . \mathrm{x} 2$ & $\mathrm{Zi}$ & table zi & $\mathrm{Fk}$ & $\mathrm{S}(\mathrm{Zi})$ & $\mathrm{F}(\mathrm{Zi})$ & $\mathrm{F}(\mathrm{Zi})-\mathrm{S}(\mathrm{Zi})$ \\
\hline 15 & 5 & 75 & -1.75 & 3.063 & 15.31 & -0.98 & 0.3365 & 1 & 0.83 & 0.666 & -0.164 \\
\hline 16 & 1 & 16 & -0.75 & 0.563 & 0.563 & -0.42 & 0.1628 & 2 & 0.6 & 0.337 & -0.263 \\
\hline
\end{tabular}


Wida Sopia Marwa \& Nani Ronsani Thamrin

Extrovert Personality and Its Impact on Students' Argumentative Essay Writing Skill

\begin{tabular}{|c|c|c|c|c|c|c|c|c|c|c|c|}
\hline 17 & 2 & 34 & 0.25 & 0.063 & 0.125 & 0.14 & 0.0557 & 3 & 0.25 & 0.444 & 0.194 \\
\hline 18 & 1 & 18 & 1.25 & 1.563 & 1.563 & 0.7 & 0.258 & 4 & 0.33 & 0.242 & -0.088 \\
\hline 19 & 2 & 38 & 2.25 & 5.063 & 10.13 & 1.26 & 0.1026 & 5 & 0.41 & 0.397 & -0.013 \\
\hline 20 & 1 & 20 & 3.25 & 10.5625 & 10.56 & 1.82 & 0.0344 & 6 & 0.5 & 0.034 & -0.466 \\
\hline$\overline{\mathrm{Mec}}$ & & 16.75 & & & & & & & & & \\
\hline Std. & & 1.785 & & & & & & & & & \\
\hline $\mathrm{L}_{0}$ & & 0.194 & & & & & & & & & \\
\hline $\mathrm{L}_{\mathrm{t}}$ & & 0.242 & & & & & & & & & \\
\hline \multicolumn{12}{|c|}{$\mathrm{Lo}<\mathrm{Lt}$} \\
\hline \multicolumn{3}{|c|}{$0.194<0.242$} & $\overline{\text { SO C }}$ & iriable & $\overline{\mathrm{PIS}}$ & e) $w$ & ormal & & & & \\
\hline
\end{tabular}

As it can be seen in table above, the data were normally distributed. EPI score was normally distributed since $\mathrm{Lo}=$ $0.194<\mathrm{Lt}=0.242$.
The result of Lilieforce normality test of argumentative essay score is described in the following table.

Table 4. Lilieforce Normality Test of Argumentative Essay Score

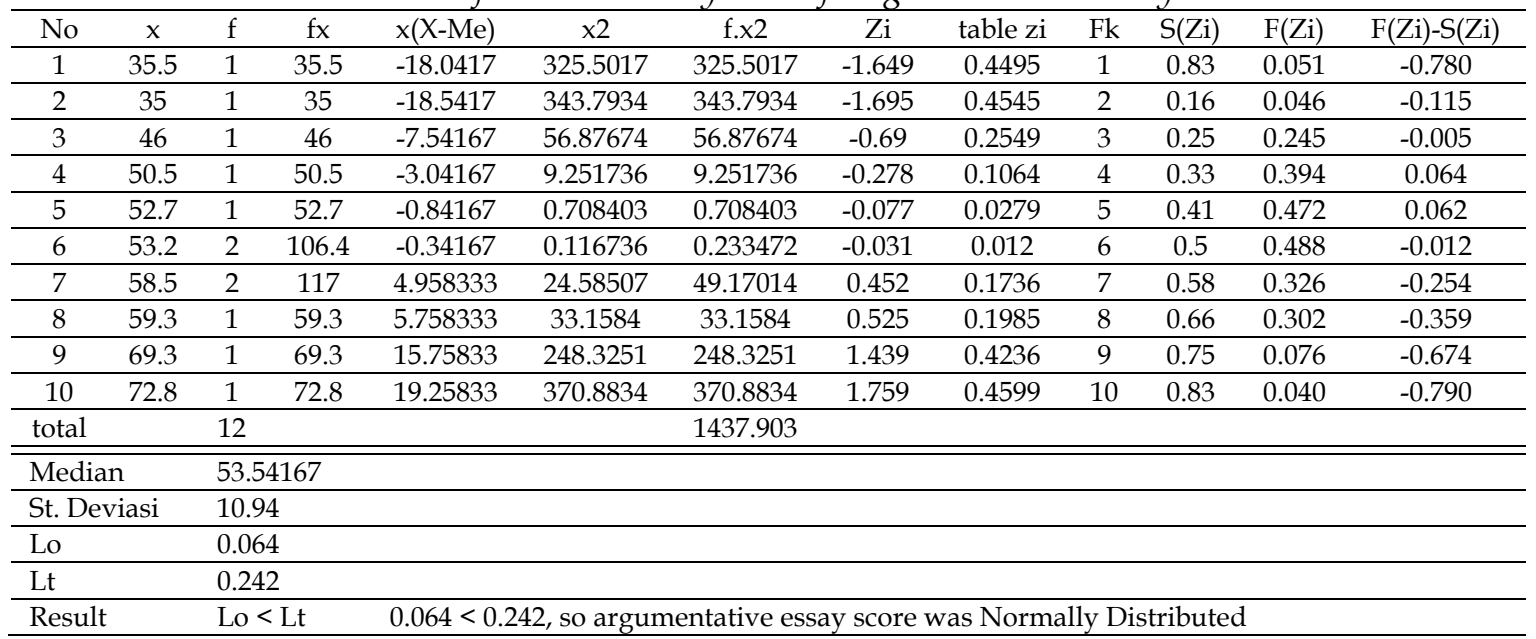

From the table above, it can be seen that the data were normally distributed. Argumentative essay score was normally distributed since $\mathrm{Lo}=0.064$ $<\mathrm{Lt}=0.242$.

After testing the normality of EPI and argumentative score, the researcher did a correlation test by using Pearson product moment correlation. Correlation test was used to determine the relationship between variable $X$ (Extrovert Personality) and variable $\mathrm{Y}$
(Argumentative Essay Writing Skill). From the calculation, it was got that the correlation score $\left(\mathrm{r}_{\text {observe }}\right)$ achieved the value 0,778 . So, $r_{\text {observe }}(0,778)>r_{\text {table }}$ $(0,576)$ with significance level was $5 \%$. Thus, it could be concluded that Ha was accepted and there was a correlation between extrovert personality and students' argumentative essay writing skill. The interpretation of $r$ value could be examined in table 5 .

Table 5. Interpretation of correlation coefficient $r$ value

\begin{tabular}{cl}
\hline Coefficient Interval & \multicolumn{1}{c}{ Correlation } \\
\hline $0.000-0.200$ & More Less (there is no correlation) \\
$0.200-0.400$ & Less \\
\hline
\end{tabular}




$\begin{array}{ll}0.400-0.600 & \text { Middle } \\ 0.600-0.800 & \text { Enough } \\ 0.800-1.000 & \text { Stronger }\end{array}$

As stated above, the correlation score between variable $X$ and variable $Y$ ( $\left.\mathrm{r}_{\text {observe }}\right)$ achieved the value 0,778 . It meant that the relationship between two variables included into enough category with correlation interval $0,600-0,800$.

After obtaining the number of product moment correlations, the researcher determined coefficient determination to analyze how far variable $\mathrm{X}$ influences variable $\mathrm{Y}$ by using the following formula:

$$
\begin{aligned}
\mathrm{KD} & =r^{2} \times 100 \% \\
& =(0,778)^{2} \times 100 \% \\
& =0,605 \times 100 \% \\
& =60 \%
\end{aligned}
$$

From the calculation of coefficient determination, the result obtained was 0.605 or $60 \%$. It meant that $60 \%$ of students' argumentative essay score was determined by their extrovert personality, remaining $40 \%$ was determined by other factors.

The final step of the data analysis was hypothesis test. The formula used to test the hypothesis was the significance test of product moment with two tail test. The following formula was used to test the hypothesis:

$$
\begin{aligned}
\mathrm{t} & =\frac{r \sqrt{n-2}}{\sqrt{1-r}} \\
& =\frac{0,778 \sqrt{12-2}}{\sqrt{1-(0,778)^{2}}} \\
& =\frac{0,778 \cdot 3,162}{\sqrt{1-0,605}} \\
& =\frac{2,460}{0,628} \\
& =3,917
\end{aligned}
$$

The analysis results of hypothesis test obtained $t_{\text {osberved }}(3,917)>t_{\text {table }}(1,782)$ with a 0,05 . So, Ha was accepted and there was a correlation between extroversion personality and students' argumentative essay writing skill.

To describe the relationship between extroversion personality and students' argumentative essay writing skill, the researcher provided a figure.

Figure 2. The relationship between extroversion personality and students' argumentative essay writing skill

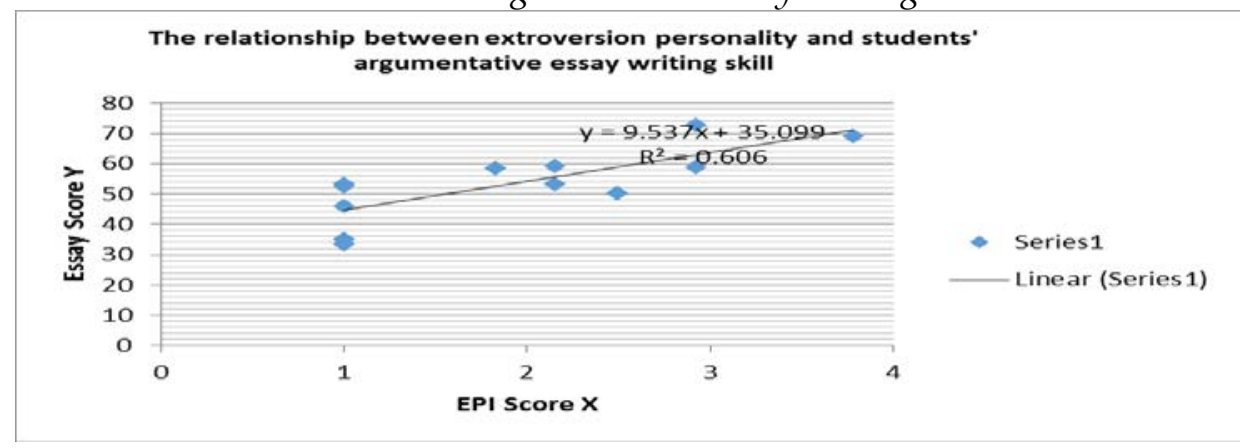

Figure 2 illustrated the scores of the argumentative essay that was plotted in $y$ axis and score for the EPI was plotted in $x$ axis. On the figure, the trend line mark was tilted to the right and it meant that two variables showed the positive correlation. The blue marker or the blue plot showed straight line, it meant that 
the correlation was strong enough. Then, $\mathrm{R}^{2}=0,606$ was the regression score. $Y$ was score of argumentative essay in which $y=$ $9,537+35.09$ that meant that argumentative scores could be predicted 9.537 times of scores of EPI plus the constant 35.09. Constant on the graph showed 35.09. It meant that the score of argumentative essay could be influenced by level of extrovert.

\section{CONCLUSION}

After doing the research and analyzing the correlation between extroversion personality and students' argumentative essay writing skill, the researcher concluded that the correlation between extroversion personality and students' argumentative essay writing skill of sophomore English Department student in University of Kuningan were categorized well.

Based on the correlation analysis, Ha hypothesis was accepted since correlation $r_{\text {observed }}(0,778)>r_{\text {table }}(0,532)$ with level of significance $5 \%$. The final result of hypothesis test was $t_{\text {observed }}$ $(3,917)>t_{\text {table }}(1,782)$ with a 0,05 . It meant that there was positive correlation between extroversion personality and students' argumentative essay writing skill

The dominant level of extraversion personality was fairly extrovert and the students who are included into fairly extrovert obtained the argumentative essay score in acceptable category.

\section{REFERENCES}

Arikunto, S. (2010). Prosedur Penelitian Suatu Pendekatan Praktik. Jakarta: Rineka Cipta.

Boroujeni, J. A. A., Roohani, A., \& Hasanimanesh, A. (2015). The impact extroversion and introversion personality types on EFL learners' writing ability, 5, 212-218. Doi

/10.17507/tpls.0501.29. 212

Eysenck, H. J., \& Eysenck, S. B. G. (1985) in Eysenk, Eysenk personality inventory. Retrieved from http://www.resourcd.com/@psychex change/file/show/968 at 28 january 2014, 06:23 am

Furnham, A. (1990). The psychology of personnel selection. New York: Cambridge University Press.

Hillocks, G. (2011). Teaching argument writing. Hanover: Pourthmont Ltd.

Lightbown, P. M., \& Spada, N. (2006). How languages are learned: Oxford handbook for language teachers (3rd ed.). Oxford: Oxford University Press.

Nama, S. N., \& Moini, F. (2013). The effect of topic bias on the writing proficiency of extrovert/introvert EFL learners, Journal of English Language Teaching and Learning, 11 (2), pp. 98-112.

Nezhad. S. H., Johandar, S., \& Khoubandenlau, M. (2014). The impact of extraversion vs. introversion on Iranian EFL learners' writing ability. Indian Journal of Fundamental and Applied Life Science. 4(1), pp. 119-128.

Newell, E. G., Vanderheid, \& Olsen, H. (2013). Learning from (and with) expert teachers of argumentative writing. Retrieved from http://www.resourcd.com/@writing prompt/ file/argumentative/.

Oshima, A., \& Hoggue, A. (2005). Writing academy English, (4 $4^{\text {th }}$ ed.). New York: Longman Ltd.

Sugiyono. (2012). Metode penelitian pendidikan pendekatan kuantitatif, kualitatif, dan $R \mathcal{E} D$. Bandung: Alfabeta.

Sullivan, J. R. (1989). Immanuel Kant's moral theory. New York: Cambridge University Press.

The Vermont Collaborative Writing. (2010). 118 retrieved from http://writingclass.ed/file /458/at 15 March 2015, 11.20 am

Wilt J., \& Revelle, W. (2000). Handbook of individual differences in social behavior. Retrieved Retrieved from http://traits.personality.edu 